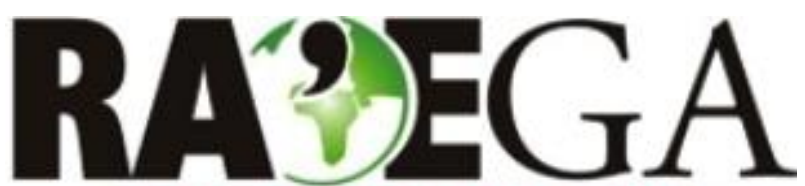

O ESPACYO GEOGRÁFICO EM ANÁLISE

\title{
ANÁLISE GEOECOLÓGICA DA PAISAGEM COSTEIRA DO MUNICÍPIO DE ARACAJU/SERGIPE
} GEOECOLOGICAL ANALYSIS OF THE COASTAL LANDSCAPE OF THE ARACAJU CITY, SERGIPE

\author{
Luana Santos Oliveira Mota ${ }^{1}$ e Rosemeri Melo e Souza ${ }^{2}$

\section{RESUMO}

O presente artigo tem por escopo realizar estudo geoecológico da paisagem costeira do munícipio de Aracaju/SE, embasado nos enfoques funcional, estrutural e antropogênico. Os procedimentos metodológicos adotados perpassaram pela avaliação das dimensões horizontal e vertical da paisagem, embasados na individualização, mapeamento e análise das unidades e subunidades geoecológicas. A partir da observação de complexos relativamente homogêneos foram delimitadas seis unidades: Terraço Marinho, Depósitos associados à Coalescência de Bancos Arenosos, Campo de Dunas, Planície de Maré, Ambientes de Sedimentação Recente e Depósitos Tecnogênicos. As unidades analisadas revelaram estruturas, formas, funções e gêneses diferenciadas, não obstante comporem a mesma unidade de relevo - a planície costeira. A gênese e estrutura das unidades estão associadas sobretudo à dinâmica fluviomarinha e às derivações antrópicas. No mosaico paisagístico estudado destaca-se a unidade dos Depósitos associados à Coalescência de Bancos Arenosos que passou por derivações de cunho natural, das quais originaram-se parte da unidade da Planície de Maré e do Campo Dunas; e derivações antrópicas, que resultaram no surgimento da unidade dos Depósitos Tecnogênicos. As funções desempenhadas pelas unidades estão associadas a zonas receptoras/acumuladoras que possuem baixo fluxo de energia e baixa altimetria - Terraço Marinho e Planície de Maré; a áreas de acumulação e dispersão - Campo de Dunas; e as Zonas Transmissoras e Receptoras/Acumuladoras - Ambientes de Sedimentação. Destaca-se, ainda, os processos geoecológicos degradantes associados a contínua intervenção antrópica, os quais tem resultado na perda de atributos e propriedades sistêmicas que garantem o cumprimento das funções geoecológicas e os mecanismos de autoregulação da paisagem avaliada.

PALAVRAS-CHAVE: unidades geoecológicas; estrutura vertical e horizontal da paisagem; derivações antrópicas.

\section{ABSTRACT}

The present article aims to conduct a geoecological study on the coastal landscape of Aracaju/SE, based on functional, structural and anthropogenic approaches. The methodological procedures adopted were the evaluation of the horizontal and vertical dimension of the landscape, based on the individualization, mapping and analysis of geoecological units and subunits. From the observation of relatively homogeneous complexes, six units were delimited: Marine Terrace, Deposits Associated with the Coalescence of Sand Banks, Dunes Field, Tidal Flat, Recent Sedimentation Environments and Technogenic Deposits. The analyzed units revealed differentiated structures, forms, functions and genesis, nevertheless they constitute the same unit of relief - the coastal plain. The genesis and structure of the units are mainly associated with fluviomarine dynamics and anthropic derivations. Regarding the landscape mosaic that has been studied, we can highlight the Deposits unit associated with the Coalescence of Sand Banks that went through natural derivations, from which part of the Tidal Flat and Dunes Field units were originated; and anthropic derivations, which resulted in the emergence of the Technogenic Deposits unit. The functions performed by the units are associated with receiver/accumulator zones that have low energy flow and low altimetry - Marine Terrace and Tidal Flat; with areas of accumulation and dispersion - Dunes field; and with Transmitter and Receiver/Accumulator Zones - Sedimentation Environments. We can also highlight degrading geoecological processes associated with the continuous anthropic intervention, which have resulted in the loss of attributes and systemic properties that guarantee the fulfillment of geoecological functions and mechanisms of selfregulation of the evaluated landscape.

KEY-WORDS: Geoecological units; Vertical and horizontal landscape structure; Anthropic derivations.

Recebido em: 17/03/2016

Aceito em: 13/11/2017

\footnotetext{
${ }^{1}$ Universidade Federal do Sergipe, UFS, Aracaju/SE, e-mail: oliveiras.lua@gmail.com

${ }^{2}$ Universidade Federal do Sergipe, UFS, Aracaju/SE, e-mail: rome@ufs.br
} 


\section{ANÁLISE GEOECOLÓGICA DA PAISAGEM COSTEIRA DO MUNICÍPIO DE ARACAJU/SERGIPE}

\section{INTRODUÇÃO}

A concretude das ações humanas no espaço revela-se na paisagem, categoria de análise geográfica cujo escopo transpõe a simples descrição da estruturação de um conjunto de objetos e formas naturais. Ao investigar uma paisagem vislumbra-se temporalidades distintas - o tempo da ação humana e o tempo da natureza, que se entrelaçam e dão origem a um sistema complexo (BERTRAND, 1972; BOLOS, 1981; RODRIGUEZ, et al 2004; TRICART, 1976).

Nessa contextura a Geoecologia surge como um dos principais métodos norteadores para o entendimento da Paisagem, uma vez que possibilita o entendimento das interações entre a dinâmica natural, que é fundamental no surgimento das paisagens e a análise das intervenções humanas, que estão assentadas sobre esse componente biofísico e são responsáveis pelas grandes alterações estruturais (TROLL, 1950; 1970).

Dentre as paisagens que apresentam maior fragilidade, destaca-se a costeira. Esta exibe grande complexidade diante das relações estabelecida entre os elementos físicos (continente, atmosfera e oceano) e antrópicos. Não obstante a intensa fragilidade, a crescente ocupação da faixa litorânea tem resultado em uma grande valorização e consequente exploração imobiliária da orla marítima. Esta é fisicamente modificada em consonância com as diferentes demandas sociais resultando em diferentes padrões de uso e ocupação.

Toda essa conjuntura vem sendo observada no litoral sergipano, em especial na cidade de Aracaju, litoral central do estado. O município tem sido alvo de intensa especulação imobiliária, fato que está provocando um reordenamento da ocupação da frente litorânea associado a grandes transformações nas estruturas naturais.

Essa problemática motivou a escolha do objeto de estudo do presente trabalho - a paisagem costeira do referido município, na qual se encontram os bairros Atalaia, Coroa do Meio e Zona de Expansão. A área é delimitada ao Norte pela desembocadura do rio Sergipe, ao Sul pela desembocadura do rio Vaza-Barris, ao Oeste pelo oceano atlântico e ao Leste pelo bairro e canal Santa Maria (Figura 1).

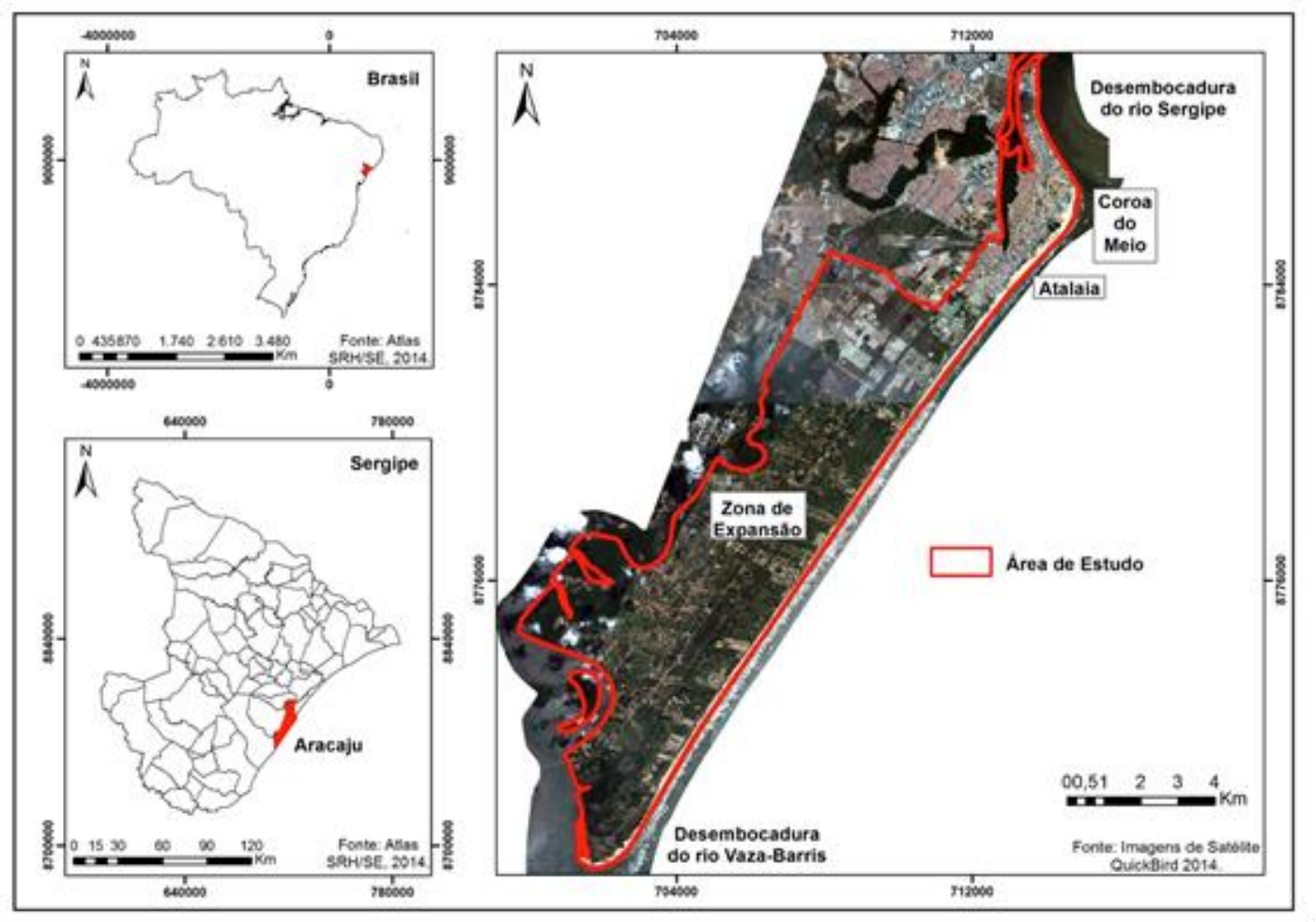

Figura 01 - Localização da área de estudo. 


\section{ANÁLISE GEOECOLÓGICA DA PAISAGEM COSTEIRA DO MUNICÍPIO DE ARACAJU/SERGIPE}

O município em estudo não possuía ocupação efetiva na orla costeira até meados da década de 1960 (MACHADO, 1989; FRANÇA;REZENDE, 2010; VILAR, 2010). Nesse período, a maior concentração populacional se encontrava na região estuarina do Rio Sergipe. 0 processo de ocupação começou a ser guiado para a frente litorânea na história recente de Aracaju, em direção incialmente aos bairros de Atalaia e Coroa do Meio. Após a fixação de aparatos urbanísticos e da população nessas localidades, inaugurou-se nova fase de ocupação reconduzida para o restante da costa aracajuana - a Zona de Expansão, que permaneceu praticamente inabitada até a década de 1980.

Todo o processo descrito foi orientado pela ação conjunta entre poder público e privado, cujas ações foram pautadas na crescente valorização do solo nos bairros costeiros e na exploração dos seus valores paisagísticos. A julgar pelo intenso processo de ocupação e pelos impactos já causados, evidencia-se a preocupação com a capacidade do ambiente costeiro em suportar tal intervenção sem ter todas as suas características suprimidas.

A composição biofísica do litoral de Sergipe e Aracajuano foram analisadas por autores como Bittencourt et al (1983), Cunha (1980), Dominguez; Bittencourt; Martin (1983), Carvalho; Fontes (2006) e Fontes (2003). Estes apresentaram estudos sobre a composição geológica e geomorfológica da paisagem costeira investigada, destacando a fragilidade das feições presentes a exemplo do terraço marinho, dos cordões litorâneos, das dunas, dos manguezais e das lagoas. Acrescenta-se ainda a este ambiente, a dinâmica das desembocaduras do rio Sergipe e Vaza-Barris, responsável por grandes alterações na paisagem ao longo das últimas décadas.

É sobre essa base biofísica, cuja análise geoecológica revela fragilidade e elevada variabilidade natural, que está ocorrendo o contínuo aumento populacional. Por conseguinte, o presente trabalho tem por escopo realizar estudo geoecológico da paisagem costeira de Aracaju assentado na delimitação das unidades e subunidades, com ênfase para os enfoques funcional, estrutural e antropogênico.

\section{MATERIAIS E MÉTODOS}

Os procedimentos adotados para concretização dos objetivos expostos englobaram quatro etapas: levantamento bibliográfico, delimitação das unidades geoecológicas da paisagem (dimensões horizontal e vertical), confecção dos mapas temáticos e integração/interpretação dos dados.

Uma vez que a dimensão horizontal da paisagem abarca o mosaico de unidades que a compõe, realizou-se a individualização das unidades geoecológicas, tendo-se por princípio básico a diferenciação tipológica e morfológica (RODRIGUEZ; SILVA; CAVALCANTI, 2004). Os aspectos considerados para delimitação foram: geológicos, geomorfológicos, bióticos e antrópicos (Quadro 1). 
MOTA, L.S.M. e SOUZA, R.M.

ANÁLISE GEOECOLÓGICA DA PAISAGEM COSTEIRA DO MUNICÍPIO DE ARACAJU/SERGIPE

Quadro 01 - Parâmetros para delimitação das unidades geoecológicas.

\begin{tabular}{|c|c|c|}
\hline Unidades & Subunidades & Descrição \\
\hline \multirow{2}{*}{ Terraço Marinho } & $\begin{array}{l}\text { Terraço Marinho a } \\
\text { Cordões Litorâneos }\end{array}$ & $\begin{array}{l}\text { Modelado de acumulação marinha de superfície levemente } \\
\text { ondulada, caracterizado pela presença de cordões litorâneos } \\
\text { lineares. }\end{array}$ \\
\hline & $\begin{array}{l}\text { Terraço Marinho } \\
\text { associadas a } \\
\text { baixios } \\
\text { úmidos/lagoas }\end{array}$ & $\begin{array}{l}\text { Baixios úmidos: porções que que entremeiam os cordões litorâneos, } \\
\text { identificados pela coloração escura. Lagoas: corpos hídricos de } \\
\text { forma circular e/ou alongada. }\end{array}$ \\
\hline \multirow{4}{*}{ Campo de Dunas } & Dunas & $\begin{array}{l}\text { Modelado de acumulação eólica caracterizado pela morfologia } \\
\text { fortemente ondulada. }\end{array}$ \\
\hline & $\begin{array}{l}\text { Dunas associadas } \\
\text { aos cordões } \\
\text { litorâneos }\end{array}$ & $\begin{array}{l}\text { Modelado de acumulação eólica sobreposto aos cordões litorâneos, } \\
\text { identificados pela sequência linear apresentado por esta feição. }\end{array}$ \\
\hline & $\begin{array}{c}\text { Depressões } \\
\text { interdunares }\end{array}$ & $\begin{array}{l}\text { Terras baixas situadas entre as dunas. Algumas associadas a baixios } \\
\text { úmidos. }\end{array}$ \\
\hline & $\begin{array}{l}\text { Dunas } \\
\text { Frontais/Lençóis de } \\
\text { Areia }\end{array}$ & $\begin{array}{l}\text { Dunas frontais: modelado de acumulação eólica, inserida no perfil } \\
\text { praia/duna, identificadas como uma crista linear paralela à praia. } \\
\text { Os lençóis de areia: não apresentam formas dunares, constituindo- } \\
\text { se como um acúmulo de sedimentos eólicos e planos. }\end{array}$ \\
\hline \multirow{3}{*}{$\begin{array}{c}\text { Ambientes de } \\
\text { Sedimentação } \\
\text { Recente (Holoceno } \\
\text { Tardio) } \\
\end{array}$} & Praia/Pós-Praia & $\begin{array}{l}\text { Faixa de areia compreendida entre a linha d'água e a base de } \\
\text { escarpas, dunas ou ocupação. }\end{array}$ \\
\hline & Pontal Arenoso & $\begin{array}{l}\text { Feição arenosa que pode apresentar forma de gancho associado as } \\
\text { adjacências das desembocaduras fluviais. }\end{array}$ \\
\hline & Bancos Arenosos & Acumulação de sedimentos defronte às desembocaduras. \\
\hline \multirow{3}{*}{ Planície de Maré } & $\begin{array}{l}\text { Intermaré } \\
\text { (Manguezal) }\end{array}$ & $\begin{array}{l}\text { Zona sujeita às oscilações diárias da maré, que bordejam canais de } \\
\text { maré e rios, identificada pela presença de sedimentos lamosos } \\
\text { recobertos pela vegetação de mangue. }\end{array}$ \\
\hline & $\begin{array}{l}\text { Supramaré } \\
\text { (Apicum) }\end{array}$ & $\begin{array}{l}\text { Zona arenosa e hipersalina que ocorre principalmente na porção } \\
\text { mais interna do manguezal. }\end{array}$ \\
\hline & Inframaré & $\begin{array}{l}\text { Porção subaquosa identificada pela presença de sedimentos } \\
\text { lamosos não recoberto pela vegetação. }\end{array}$ \\
\hline $\begin{array}{l}\text { Depósito associado } \\
\text { à coalescência de } \\
\text { bancos arenosos }\end{array}$ & \multicolumn{2}{|c|}{$\begin{array}{c}\text { Identificado a partir de fotografias aéreas antigas e cartas náuticas, em razão da migração e } \\
\text { posterior anexação de bancos arenosos à costa. }\end{array}$} \\
\hline $\begin{array}{c}\text { Depósitos } \\
\text { Tecnogênicos }\end{array}$ & \multicolumn{2}{|c|}{$\begin{array}{l}\text { Identificado a partir da interpretação de fotografias aéreas e da execução de sondagens } \\
\text { simples. }\end{array}$} \\
\hline $\begin{array}{l}\text { Áreas Ocupadas/ } \\
\text { Loteamentos } \\
\text { (Entremeiam todas } \\
\text { as unidades } \\
\text { geoecológicas) }\end{array}$ & \multicolumn{2}{|c|}{$\begin{array}{l}\text { Área ocupada: alta densidade de ocupação, identificadas por conjuntos habitacionais, } \\
\text { casas, condomínios, bares e restaurantes etc. } \\
\text { Loteamentos: áreas loteadas cuja ocupação é incipiente, mas que demarcam áreas que } \\
\text { provavelmente terão ocupação efetiva. Estas áreas são identificadas a partir do padrão } \\
\text { retangular, separado por vias ou não, que diferem das áreas do seu entorno; Vias de } \\
\text { Ligação. }\end{array}$} \\
\hline
\end{tabular}

Como a presente pesquisa tem por escopo a realização de uma análise pormenorizada, em que se pretende abarcar a estrutura tipológica e funcional das unidades geoecológicas, os mapeamentos realizados enquadram-se nos mapas detalhados e muito detalhados, já que a escala de análise variou de $1: 2.000$ até $1: 100.000$.
Os mapas representativos da individualização das unidades e subunidades geoecológicas foram confeccionados no programa de geoprocessamento ArcGIS 10.2.1, com suporte na interpretação de imagens de satélite QuickBird de 2014 associada à verificação em campo. As classes temáticas adotadas e suas características estão expostas no quadro 1. 


\section{ANÁLISE GEOECOLÓGICA DA PAISAGEM COSTEIRA DO MUNICÍPIO DE ARACAJU/SERGIPE}

As unidades mapeadas foram quantificadas com auxílio da ferramenta Calculate Geometry do programa ArcGIS 10.1.2.

Somado à análise horizontal da paisagem, construíram-se os perfis transversais visando ao entendimento da estrutura vertical, primordial à análise geoecológica. Foram individualizados quatro transectos em diferentes pontos da área estudada, perpassando por diversas unidades. A escolha dos pontos para a realização dos perfis deu-se em razão da composição da paisagem, uma vez que os perfis realizados abarcaram a maior quantidade de unidades/subunidades presentes na área investigada.

A construção dos perfis levou em consideração cinco fatores: o compartimento morfoescultural, as unidades geoecológicas, as características edáficas, a vegetação original e as características climáticas. Os perfis foram construídos com respeito as dimensões espaciais. Inserida nos procedimentos empregados para análise das unidades geoecológicas, destaca-se a identificação da unidade dos depósitos tecnogênicos, a qual se deu através da interpretação de fotografias aéreas e da execução de sondagens simples e reconhecimento de solo com uso de trado no bairro Coroa do Meio. As sondagens foram limitadas pela presença do lençol freático e pelo próprio material constituinte que impediu a penetração. Todas foram executadas pelo método de simples reconhecimento de solo, observando as normas 9.603/15 e 6.484/01, da ABNT (Associação Brasileira de Normas Técnicas).

\section{RESULTADOS E DISCUSSÕES}

A individualização das unidades e subunidades geoecológicas fundada no panorama horizontal (Figura 2), evidenciou que a estrutura espacial da área estudada se apresenta em forma de mosaico com elevada diversidade tipológica, mesmo compondo a mesma unidade de relevo - a planície costeira. 


\section{ANÁLISE GEOECOLÓGICA DA PAISAGEM COSTEIRA DO MUNICÍPIO DE ARACAJU/SERGIPE}

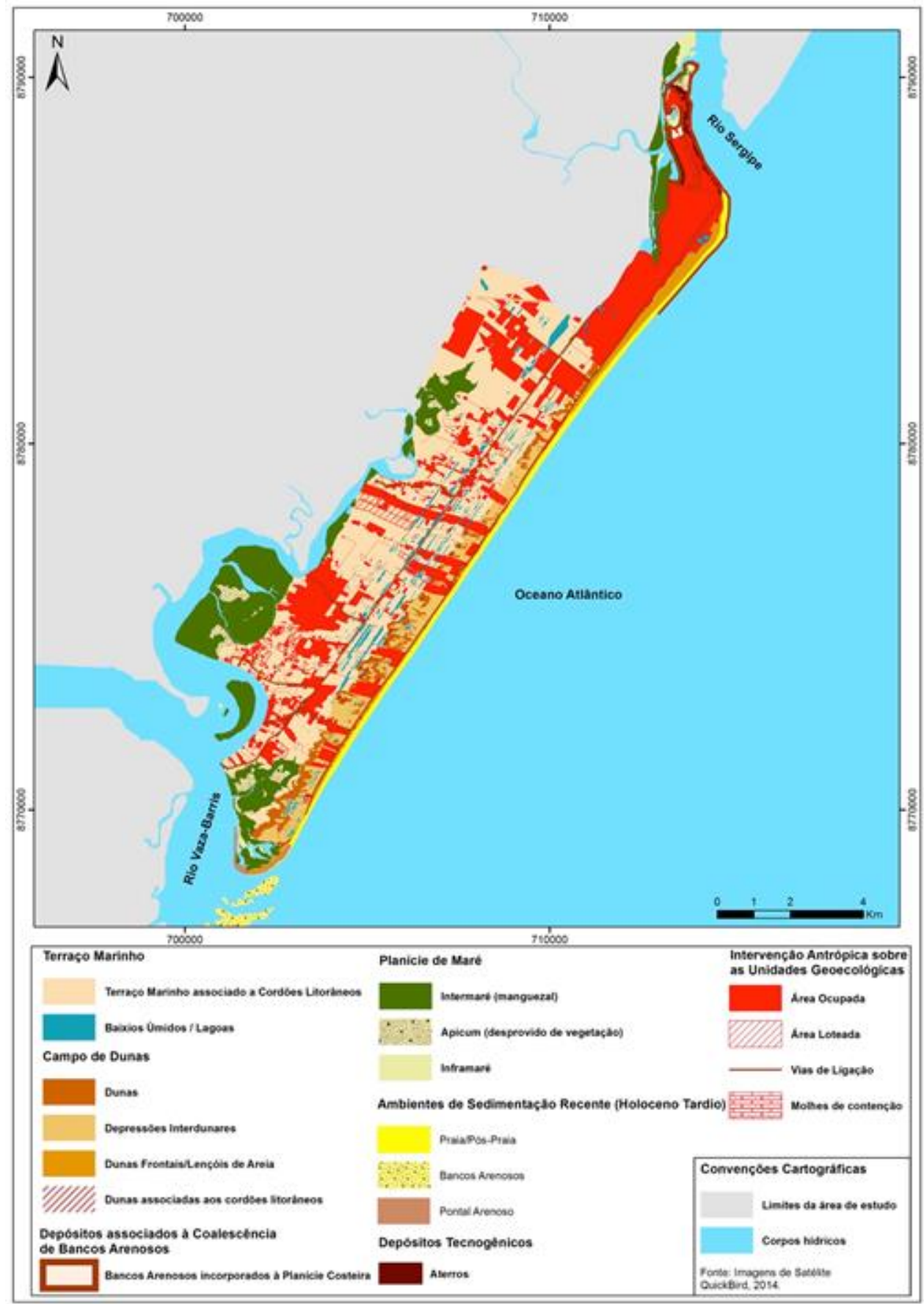

Figura 02 - Delimitação das Unidades Geoecológicas da Paisagem Costeira de Aracaju/SE.

Dentre as unidades geoecológicas identificadas enfatiza-se inicialmente a unidade dos depósitos associados aos bancos arenosos coalescidos, em razão da gênese e evolução diferenciadas. Esta unidade, onde atualmente está localizado o bairro Coroa do Meio, foi originada a partir da migração e anexação de coroas arenosas localizadas no interior da desembocadura do rio Sergipe ao continente. Embora enquadrada em mapas geológicogeomorfológicos (CPRM) como Terraço Marinho Holocênico, as análises pormenorizadas aqui realizadas revelaram que não se trata em verdade dessa unidade geomorfológica.

Para além das cartas náuticas que atestam a anexação de bancos arenosos a esta 


\section{ANÁLISE GEOECOLÓGICA DA PAISAGEM COSTEIRA DO MUNICÍPIO DE ARACAJU/SERGIPE}

porção da costa entre os anos de 1823 e 1914 , não há registro de cordões litorâneos nessa extensão, típicos de toda a planície costeira de Aracaju associada a Terraços Marinhos. Assim, optou-se por individualizá-la em uma única unidade. Outro aspecto que a torna peculiar é o fato de ter passado por processos de derivação natural, que resultou no surgimento de parte de outras unidades geoecológicas - planície de maré e campo de dunas; e processos de derivação antropogênica que deram origem aos depósitos tecnogênicos. Por essa razão a referida unidade aparece delimitada na figura 2 , embora sua área não tenha sido contabilizada, o que se deu em razão de ter sido acrescida nas unidades derivadas destacadas.
A fim de subsidiar a análise, realizou-se o cálculo de áreas de cada unidade e subunidade geoecológica da paisagem, demonstrados na tabela 1.

Com suporte nos dados do atual cenário da paisagem (2014), merece destaque aspecto relacionado à predominância de cada unidade na estrutura espacial da paisagem. As paisagens dominantes são o Terraço Marinho, que compõe a maior parte da área de estudo, e as Áreas de Intervenção Antrópica. Já as paisagens subdominantes são constituídas pela Planície de Maré, o Campo de Dunas, os Ambientes de Sedimentação Recente e os Depósitos Tecnogênicos.

Tabela 01 - Área das Unidades Geoecológicas da Paisagem Costeira de Aracaju/SE.

\begin{tabular}{|c|c|c|c|c|}
\hline Unidade Geoecológica & Subunidades & $\begin{array}{c}\text { Área } \\
\text { em Km² }\end{array}$ & $\begin{array}{c}\text { Intervenção } \\
\text { Antrópica em Km² }\end{array}$ & $\begin{array}{c}\text { Total da } \\
\text { Unidade* em } \\
\mathrm{Km}^{2}\end{array}$ \\
\hline \multirow[t]{3}{*}{ Terraço Marinho } & $\begin{array}{c}\text { Terraço Marinho associado } \\
\text { aos cordões litorâneos }\end{array}$ & 43,6 & \multirow{3}{*}{16,8} & \multirow{3}{*}{28,8} \\
\hline & Baixios Úmidos/Lagoas & 2 & & \\
\hline & Total da Unidade & 45,6 & & \\
\hline \multirow[t]{4}{*}{ Campo de Dunas } & Dunas & 2,5 & \multirow{4}{*}{2,5} & \multirow{4}{*}{8,2} \\
\hline & Depressões interdunares & 5,9 & & \\
\hline & $\begin{array}{c}\text { Dunas Frontais/Lençóis de } \\
\text { Areia }\end{array}$ & 2,3 & & \\
\hline & Total da Unidade & 10,7 & & \\
\hline \multirow[t]{4}{*}{ Planície de Maré } & Intermaré (manguezal) & 11,9 & \multirow{4}{*}{2,2} & \multirow{4}{*}{11,5} \\
\hline & Supramaré (apicum) & 1,2 & & \\
\hline & Inframaré & 0,6 & & \\
\hline & Total da Unidade & 13,7 & & \\
\hline \multirow[t]{2}{*}{ Depósitos Tecnogênicos } & - & 1,31 & \multirow[b]{2}{*}{1,2} & \multirow[b]{2}{*}{0,11} \\
\hline & Total da Unidade & 1,31 & & \\
\hline \multirow{4}{*}{$\begin{array}{l}\text { Ambientes de Sedimentação } \\
\text { Recente (Holoceno Tardio) }\end{array}$} & Praia/Pós-Praia & 2,3 & \multirow{4}{*}{0} & \multirow{4}{*}{4,4} \\
\hline & Bancos Arenosos & 1,7 & & \\
\hline & Pontal Arenoso & 0,4 & & \\
\hline & Total da Unidade & 4,4 & & \\
\hline
\end{tabular}

* Área da Unidade Geoecológica (-) Área de Intervenção Antrópica

Partindo para a análise da estrutura vertical da paisagem, segundo componente da análise estrutural, inicialmente traz-se quatro perfis transversais da área estudada, perpassando por todas as unidades mapeadas (Figura 3). Levou-se em consideração cinco aspectos: compartimento morfoescultural, unidades geoecológicas da paisagem, pedologia, vegetação original e características climáticas.
Constatou-se que se trata de uma paisagem composta por apenas uma unidade morfoescultural - a Planície Costeira, a despeito de possuir grande diversidade de unidades e subunidades. Tal multiplicidade é justificada pelo fato de esta paisagem constituir-se como um ambiente de interface continente-oceano de elevada dinamicidade e no qual se encontram vários agentes atuantes na formação e transformação da paisagem. 
MOTA, L.S.M. e SOUZA, R.M

ANÁLISE GEOECOLÓGICA DA PAISAGEM COSTEIRA DO MUNICÍPIO DE ARACAJU/SERGIPE

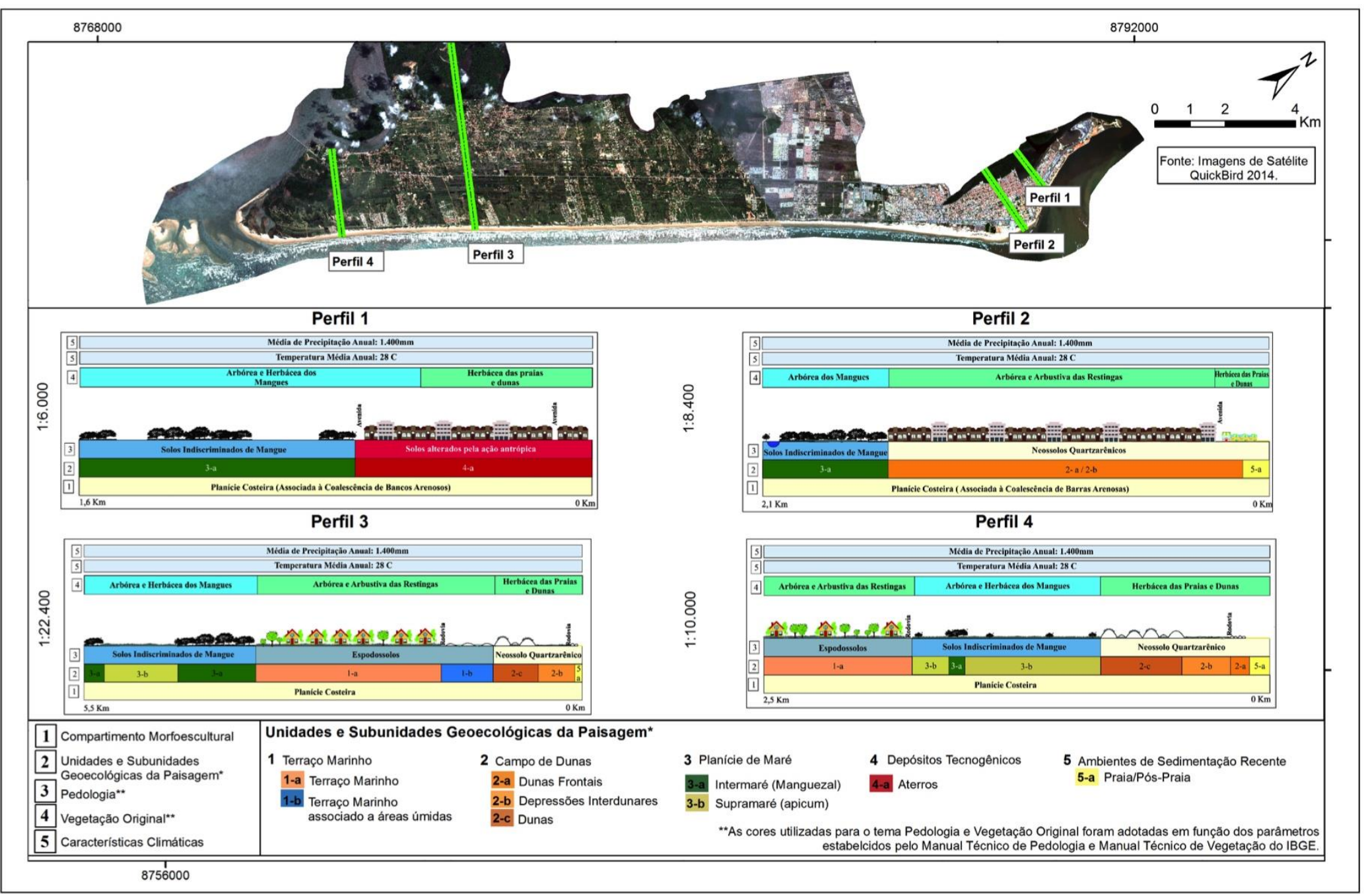

Figura 03 - Estrutura Vertical das Unidades Geoecológicas da Paisagem Costeira de Aracaju/SE. 


\section{ANÁLISE GEOECOLÓGICA DA PAISAGEM COSTEIRA DO MUNICÍPIO DE ARACAJU/SERGIPE}

No que se refere aos tipos de solo, três tipos compõem os perfis analisados: os Espodossolos, associados ao Terraço Marinho; os Solos Indiscriminados de Mangue, associados à Planície de Maré; e os Neossolos Quartzarênicos, associados aos Ambientes de Sedimentação Recente, ao Campo de Dunas e aos Depósitos associados à Coalescência de Bancos Arenosos.

Relativo à classificação dos solos, acentua-se pequena divergência quanto ao setor que engloba os perfis 1 e 2 , inseridos no bairro Coroa do Meio. Conforme classificação da EMBRAPA (2004), a referida área é composta por solos do tipo do Espodossolos. No entanto, a análise do processo evolutivo somada às sondagens realizadas apontou que os solos que compõem essa área possuem características muito mais próximas aos Neossolos Quartazênicos. Já no tocante ao processo evolutivo, além da origem estar relacionada à anexação de bancos arenosos, o tempo de formação desta unidade é relativamente curto, cerca de 100 anos, de modo que é improvável que processos pedogenéticos configurem solos do tipo Espodossolos. Além dessa circunstância, nas sondagens realizadas, com profundidades de até $150 \mathrm{~cm}$, não foi encontrado horizonte $B$ espódico, típicos dos Espodossolos, em nenhum dos cinco pontos de coleta. A análise granulométrica do material relativo às amostras coletadas indicou a classificação textural FrancoArenosa.

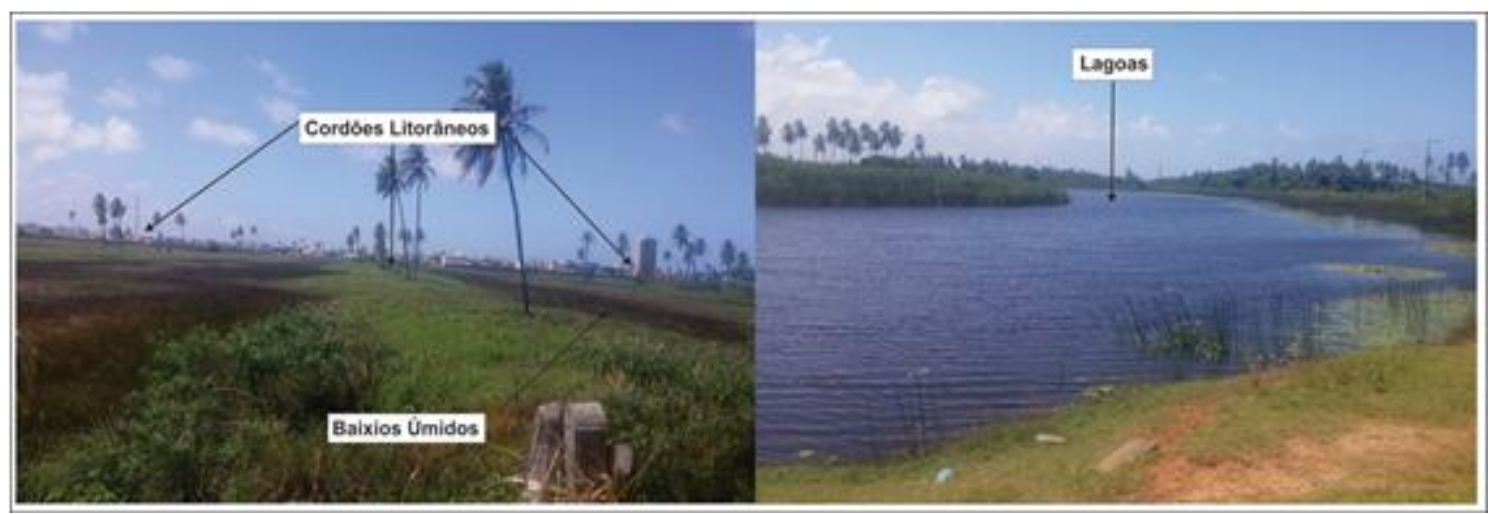

Figura 04 - Subunidades associadas ao Terraço Marinho. Registro Fotográfico das Autoras (2016).

Por integrar uma planície costeira quaternária de caráter progradacional, a unidade do Terraço Marinho é composta por uma
Quanto aos tipos de vegetação, verificou-se basicamente a existência de arbórea e herbácea de mangue associadas à Planície de Maré; arbórea e arbustiva das restingas associadas ao Terraço Marinho; e herbácea e cactáceas associadas ao Campo de Dunas e aos Ambientes de Sedimentação Recente.

O último elemento da estrutura vertical é o relativo às características climáticas. Todos os perfis analisados estão incluídos dentro um único tipo climático (em função da escala adotada), Tropical Litorâneo do Nordeste Oriental, com características muito semelhantes, tanto de precipitação quanto de temperatura.

\section{UNIDADE GEOECOLÓGICA DO TERRAÇO} MARINHO

Nessa unidade preponderam as áreas planas, marcadas por pequenas ondulações advindas da existência dos cordões litorâneos, entremeados por baixios úmidos e, por vezes, alagados. A ação pedogenética sobre o material de origem configurou solos do tipo Espodossolos. Toda esta área é recoberta por vegetação típica de restingas (arbórea, arbustivas e herbáceas).

Tendo em vista tais características, individualizou-se o Terraço Marinho em duas subunidades: o Terraço Marinho associado aos cordões litorâneos e o Terraço Marinho associado aos baixios úmidos e as lagoas (Figura 4). 


\section{ANÁLISE GEOECOLÓGICA DA PAISAGEM COSTEIRA DO MUNICÍPIO DE ARACAJU/SERGIPE}

são uniformes e paralelos, o que de acordo com Cunha (1980) indica a estabilidade da costa.

A outra subunidade, Terraço Marinho associado aos baixios úmidos e às lagoas, está diretamente ligado à subunidade dos cordões litorâneos. Esse subambiente é caracterizado por zonas com pequenos declives, alimentados por águas subterrâneas e pluviais, visualizado em quase toda a extensão do Terraço Marinho e, a depender da época do ano, primordialmente nos meses de chuva, pode vir a constituir pequenas áreas alagadas. Mesmo em períodos mais secos ainda é possível visualizar o solo relativamente encharcado. Dessa forma, a referida subunidade constitui um indicativo extremamente importante de áreas mais suscetíveis à inundação em períodos chuvosos.

As Lagoas apresentam características similares aos baixios úmidos em razão da sua associação aos períodos chuvosos e secos. Algumas destas são perenes, mas a grande parte delas são intermitentes, surgindo apenas em períodos chuvosos. Tal como os baixios úmidos, em períodos secos as lagoas podem deixar de existir, mas o solo ao qual elas estão associadas tende a permanecer úmido.

Como demonstrado, o Terraço Marinho apresenta relativamente grandes extensões, de modo que a linha de costa atual dista em até 7 $\mathrm{km}$ da linha de falésias inativas. Essas originadas pela ação erosiva do mar na Formação Barreiras durante a Transgressão mais antiga (BITTENCOURT et al, 2002). Ressalta-se, ainda, que a planície costeira de Aracaju compreende apenas os terraços marinhos de origem holocênica.

Diante do exposto e alicerçado nas considerações sobre a gênese da paisagem realizada por Rodriguez; Silva; Cavalcanti (2004), salienta-se que a paisagem estudada possui o seu tipo genético caracterizado como hidrodinâmica acumulativa, em que se destaca a ação fluvial e, principalmente, marinha, para sua composição.

No tocante às funções geoecológicas da supracitada unidade, esta constitui uma área de acumulação, uma vez que se caracteriza como uma planície associada à incorporação de materiais provenientes de outras unidades que, no presente caso, referem-se aos tabuleiros costeiros localizados externamente aos terraços, assim como dos materiais trazidos e acumulados pela ação fluviomarinha. Já a partir da classificação de Dias; Oliveira (2012) o Terraço Marinho está incluído nas zonas receptoras/acumuladoras por possuir baixo fluxo de energia, baixa altimetria e grandes extensões.

\section{UNIDADE GEOECOLÓGICA DO CAMPO DE DUNAS}

A unidade do Campo de Dunas é composta por quatro subunidades: as dunas, as dunas frontais/lençóis de areia, as depressões interdunares e as dunas associadas aos cordões litorâneos (Figura 5).

Essa unidade corresponde a 10,8\% da paisagem costeira estudada, com o predomínio de áreas onduladas entremeadas por declives, recobertos por vegetação de restinga do tipo herbáceas associada a solos do tipo Neossolos Quartzarênicos.

A referida unidade constitui, quanto à função geoecológica, uma área de acumulação, resultante da aglomeração de sedimentos provenientes do retrabalhamento eólico. Uma vez que possuem tais características, também podem ser incluídas nas áreas dispersoras, tendo em vista o constante retrabalhamento e movimentação de sedimentos, principalmente nas dunas frontais.

As dunas fixas encontradas na área de estudo estão associadas à terceira geração de dunas, descritas por Bittencourt et al (1983) como dunas parabólicas originadas no quaternário e dispostas sobre os terraços marinhos holocênicos. 


\section{ANÁLISE GEOECOLÓGICA DA PAISAGEM COSTEIRA DO MUNICÍPIO DE ARACAJU/SERGIPE}

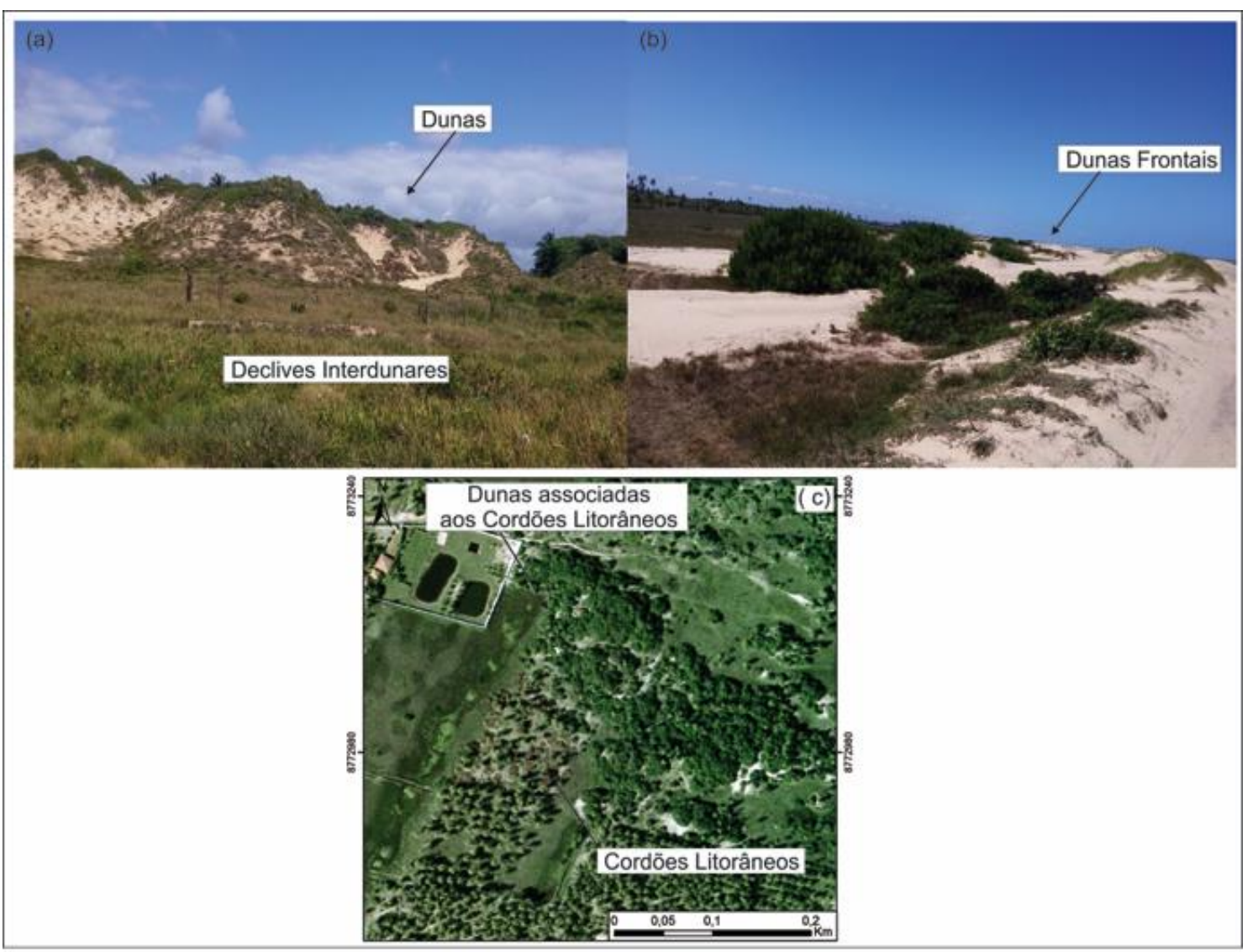

Figura 05 - Subunidades do Campo de Dunas. Em (a) e (b) Registro Fotográfico das autoras (2016). Em (c) Ortofotos de 2004.

Em alguns casos as dunas são completamente recobertas por vegetação, o que impede a mobilização destas. Em outros, geralmente nas dunas mais próximas à frente litorânea, em que a vegetação é mais escassa, há certo grau de remobilização dos sedimentos pela ação eólica, dando origem a pequenas bacias de deflação (blowouts).

As dunas são separadas por pequenas depressões interdunares. Na paisagem estudada encontram-se: interdunas, cuja superfície de deposição é seca; associadas a baixios úmidos, as quais apresentam caráter sazonal; e as alagadas, quando associadas a lençóis freáticos localizados próximos à superfície.

As dunas frontais correspondem ao cordão dunar localizado na interface da unidade do campo de dunas e da praia/pós-praia (Ambientes de Sedimentação Recente) e, como resultado, têm sua dinâmica estreitamente relacionada a ambas as unidades. Essa feição é encontrada em quase toda extensão da costa aracajuana, possuindo morfologias diferenciadas.

Sobressai-se nessa paisagem certa peculiaridade quanto à combinação entre dunas e cordões litorâneos, tal como destacado anteriormente (vide figura 5-c). É recorrente nesta unidade a migração de dunas sobre as sequências de cordões litorâneos, razão pela qual optou-se em compartimentar tal singularidade como uma subunidade.

\section{UNIDADE GEOECOLÓGICA DA PLANÍCIE DE MARÉ}

A unidade da Planície de Maré compõe $15,3 \%$ da paisagem costeira em análise. Sua gênese está associada aos depósitos holocênicos de origem marinha e fluvial que constituíram uma planície fluviomarinha. Está combinada a Solos Indiscriminados de Mangue, em sua maioria recobertos pela vegetação típica dos manguezais. 


\section{ANÁLISE GEOECOLÓGICA DA PAISAGEM COSTEIRA DO MUNICÍPIO DE ARACAJU/SERGIPE}

A referida unidade apresenta áreas planas, por onde perpassam canais com baixas velocidades de escoamento influenciados pelas variações das marés. Das características morfológicas encontradas nessa unidade advêm três subambientes, também classificados como subunidades (Figura 6). As áreas de inframaré, cujo substrato se encontra permanentemente alagado; as áreas de intermaré, em que as variações das marés resultam no alagamento periódico; e as áreas de supramaré, não atingidos pelas marés, com substrato constantemente ressequido.

No que se refere a sua função geoecológica, é um ambiente de acumulação, podendo ser classificado ainda como uma Zona Receptora/Acumuladora, distinguindo-se pelo baixo fluxo de energia e baixos declives.

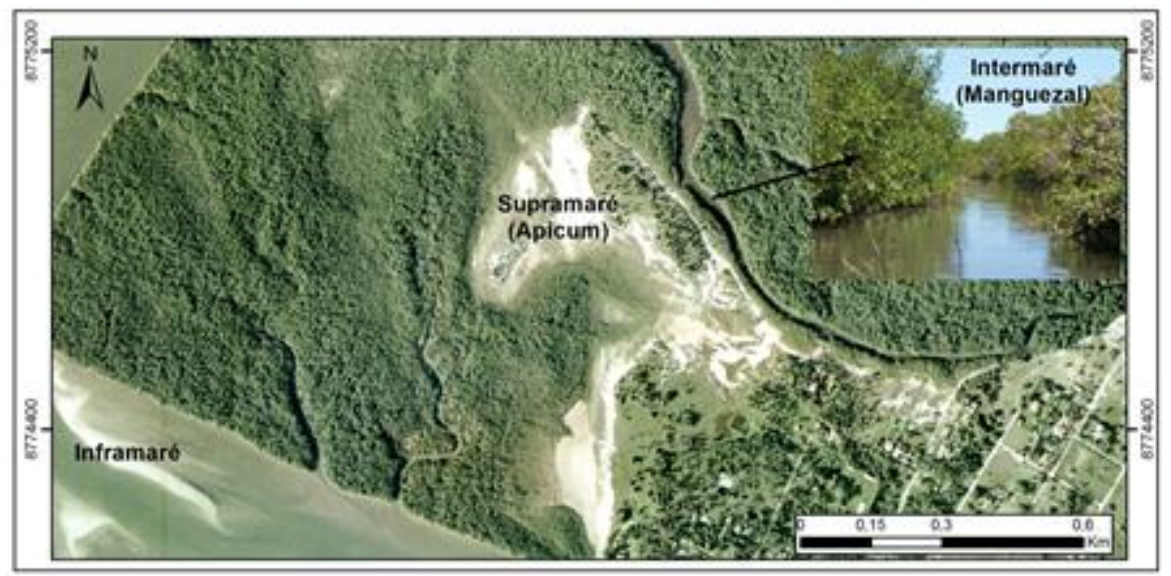

Figura 06 - Subunidades da Planície de Maré. Fonte: Ortofotos, 2004.

A subunidade intermaré (manguezal) constitui a maior parte da unidade da Planície de Maré, presente majoritariamente nas proximidades dos canais fluviais contidos na área.

Já a subunidade supramaré (apicum), localizada majoritariamente no interior dos manguezais, é classificada basicamente como apicuns inclusos. Sua origem está interligada à deposição de areias finas durante as enchentes de preamar, processo que torna o ambiente arenoso, suprimindo a vegetação. A áreas de inframaré, porções subaquosas, dispõem da menor área da Unidade, desprovidas de vegetação. São visíveis, em geral, quando das marés baixas.

As subunidades de intermaré, supramaré e inframaré são inter-relacionadas na medida em que a evolução de uma pode culminar no desenvolvimento da outra. 0 desenvolvimento de planícies de maré associada à margem direita do rio Sergipe e à margem esquerda do rio Vaza-Barris estão associadas à evolução de áreas de inframaré para intermaré em razão da colonização daquele ambiente pela vegetação de mangue.

A origem da planície de maré, localizada nas adjacências do rio Sergipe, está interligada ao surgimento de uma área protegida da ação das ondas associada à anexação de bancos arenosos à costa, o qual possibilitou o acúmulo de sedimentos finos, posteriormente colmatados, que deram origem à referida planície de maré.

Já a origem planície de maré localizada nas proximidades do rio Vaza-Barris está ligada ao surgimento de um pontal arenoso na margem esquerda desta desembocadura, que propiciou o surgimento de um ambiente de baixa energia. $O$ processo de isolamento da antepraia iniciou-se após 1978, mas só em 1986 foi possível visualizar o acúmulo sedimentar referente ao inicio da formação da planície de maré. Na área isolada, retaguarda do pontal, a dinâmica das marés passou a predominar e a favorecer a ocorrência do processo de colmatação, no qual os sedimentos finos (silte e argila), em suspensão na lâmina d'água, foram depositados preenchendo parcialmente o ambiente aquoso. 


\section{ANÁLISE GEOECOLÓGICA DA PAISAGEM COSTEIRA DO MUNICÍPIO DE ARACAJU/SERGIPE}

\section{UNIDADE GEOECOLÓGICA DOS AMBIENTES DE SEDIMENTAÇÃO RECENTE (HOLOCENO TARDIO)}

É a unidade que está em contato direto com os agentes fluviais e marinhos, caracterizando-se como áreas de elevada dinamicidade, sujeitas a transformações constantes e em curtos períodos de tempo se comparado às outras unidades apresentadas.

No que concerne à extensão, é a menor unidade, perfazendo cerca de $5,8 \%$ do total da paisagem estudada. Os solos caracterizam-se como Neossolos Quartzarênicos, recobertos por vegetação majoritariamente do tipo herbácea. Tendo em vista as características morfológicas, a presente unidade foi fracionada em três subunidades: a praia/pós-praia, o pontal arenoso e os bancos arenosos (Figura 7).

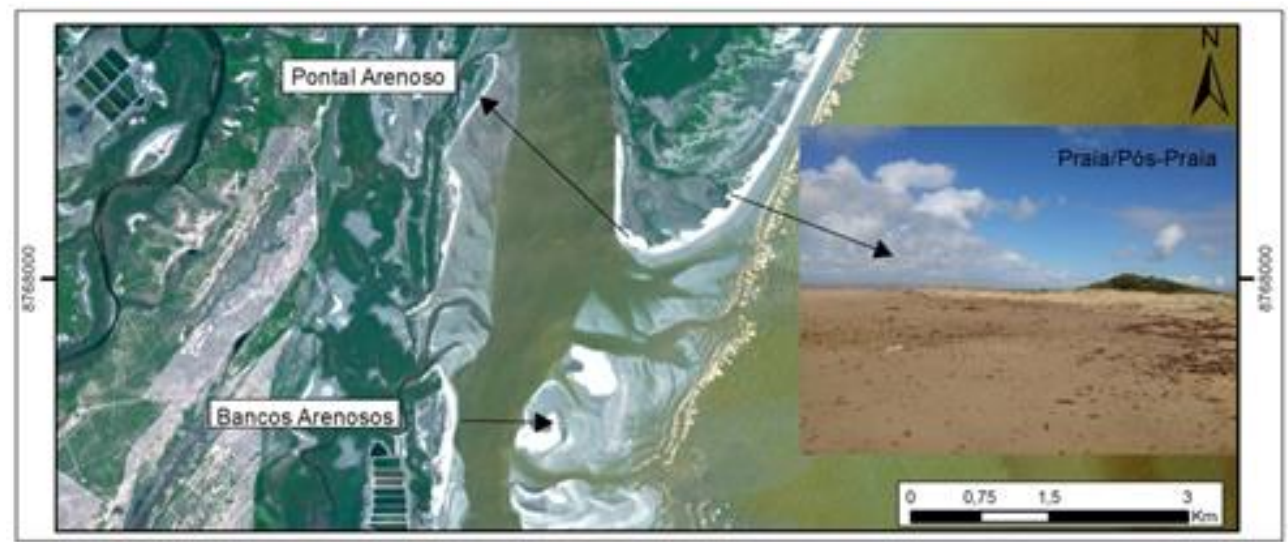

Figura 07 - Subunidades dos Ambientes de Sedimentação Recente (Holoceno Tardio). Fonte: Imagens de Satélite RapidEye (2014).

Quanto à função geoecológica, a unidade dos Ambientes de Sedimentação Recente classifica-se, tal como todas as outras unidades, como uma área de acumulação. Já na perspectiva da classificação proposta por Dias; Oliveira (2012), dito ambiente é uma Zona Transmissora e Receptora/Acumuladora, pois se caracteriza como área de contato entre o continente e o oceano. Difere-se das outras unidades por possuir baixos declives, ao tempo em que constituem ambientes de elevados fluxos de energia, sujeitos a processos constantes de erosão e sedimentação que resultam em alto grau de retrabalhamento das feições.

As praias situadas na área de estudo possuem características similares, podendo ser associadas a praias do tipo dissipativa em razão das características morfológicas identificadas: largas extensões, baixas declividades, elevada exposição, sedimentos de textura finas e zona de arrebentação larga. Ressalvam-se apenas as praias da Atalaia e dos Artistas, cuja morfologia apresenta bermas, não visualizadas no restante das praias estudadas.

No que pertence à subunidade do pontal arenoso, destaca-se seu processo evolutivo dentre o período de 1965 e 2014, descrito anteriormente por Oliveira (2012). Esta feição teve sua gênese relacionada à retenção de sedimentos trazidos pelas correntes costeiras de sentindo preferencial NE para SW, a qual deu origem a uma linha de retenção e proporcionou $o$ acúmulo de sedimentos na margem esquerda da desembocadura do rio Vaza-Barris. O seu crescimento esteve associado à dinâmica do delta de maré-vazante presente na área.

Já os bancos arenosos são definidos como acumulações de areia, defronte às desembocaduras, tendo sua gênese vinculada à interação das correntes de maré e das correntes geradas pelas ondas, ou seja, da corrente longitudinal (FITZGERALD, 1984).

A análise evolutiva dos bancos arenosos realizada por Mota (2014) mostrou que eles 


\section{ANÁLISE GEOECOLÓGICA DA PAISAGEM COSTEIRA DO MUNICÍPIO DE ARACAJU/SERGIPE}

tiveram dimensões e posicionamentos diferenciados ao longo de tempo. Na análise realizada para o ano de 2014 os bancos arenosos possuíam grandes proporções, totalizando uma área de cerca de $2.280 \mathrm{~m} 2$.

\section{UNIDADE GEOECOLÓGICA DOS DEPÓSITOS TECNOGÊNICOS}

Esta unidade é caracterizada como uma derivação antropogênica da Planície de Maré e do Campo de Dunas existentes na margem direita do rio Sergipe, circunscrita ao bairro Coroa do Meio. Tal processo foi descrito inicialmente por Mota (2017).
Com base em interpretações de fotografias aéreas antigas e análises de solo foi possível identificar e caracterizar os depósitos presente na área. Constatou-se que esse bairro se consolidou posteriormente à supressão do manguezal e ao aterramento da Planície de Maré (1a fase do aterro). Após a conclusão das obras relacionadas à urbanização da Coroa do Meio, novas áreas foram aterradas para a construção dos molhes de contenção nas proximidades da margem direita do rio Sergipe (2a fase do aterro), após a década de 1990 (Figura 8).

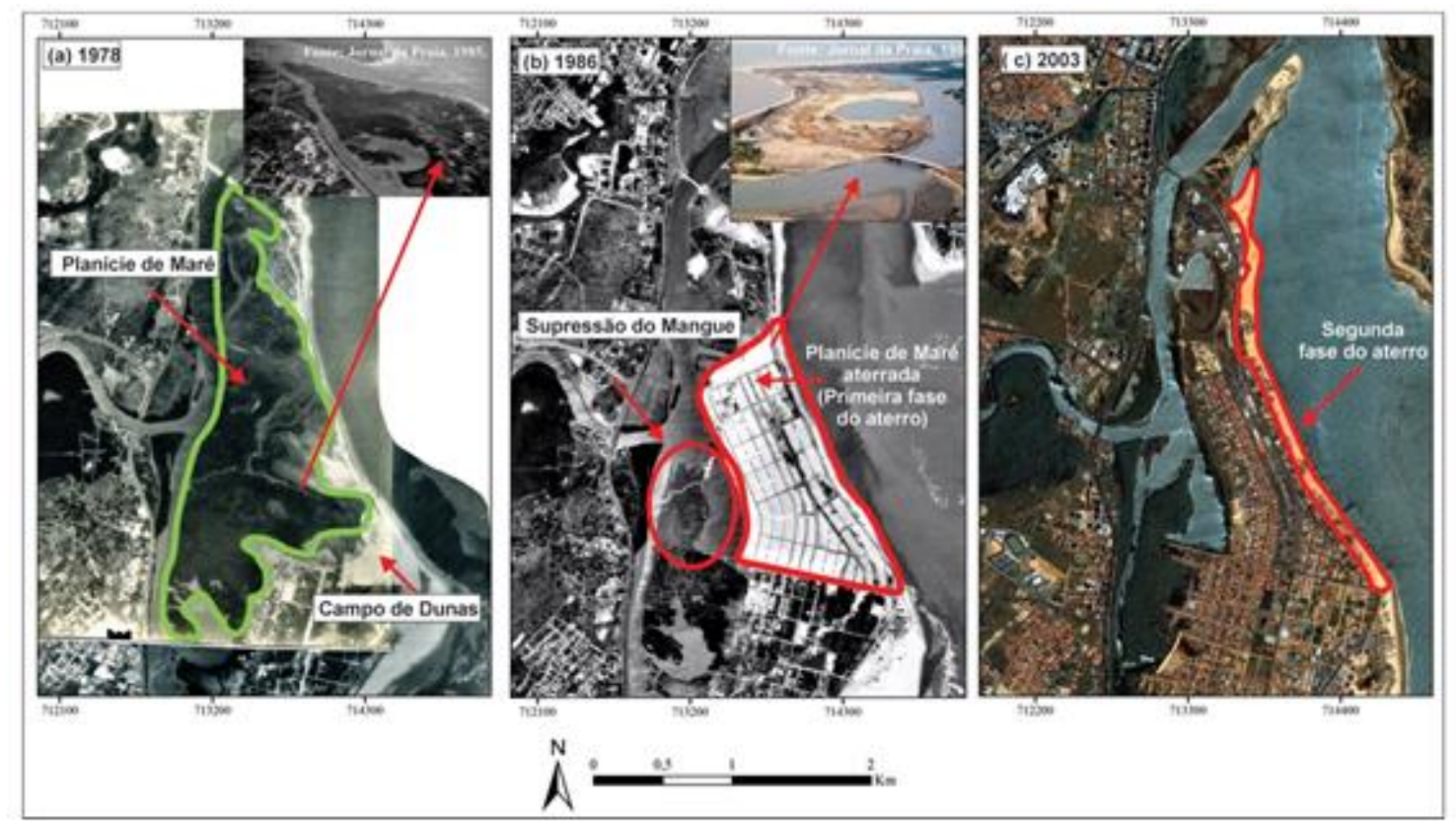

Figura 08 - Evolução dos Depósitos Tecnogênicos no bairro Coroa do Meio. Fonte: Fotografias aéreas de 1978 e 1986; Imagens de Satélite QuickBird (2003).

Derivados do processo de remobilização de sedimentos da planície de maré, os depósitos tecnogênicos circunscritos à primeira fase do aterro, mesmo não apresentando artefatos de origem antrópica em sua composição, foram assim classificados em função da sua gênese ser resultante da influência humana direta que se deu através dos processos de deslocamento de sedimentos, sendo o material constituinte dos depósitos predominantemente natural.

Concernente aos testemunhos da 2a fase do aterro, a atuação antrópica deu-se de forma diferenciada. Ainda que se caracterizem como Depósitos Construídos, em razão da atuação humana direta, nestes se constatou a presença de artefatos humanos nas camadas mais profundas do aterro, o que caracteriza esta porção como depósitos constituídos por Materiais Úrbicos.

\section{A INTERVENÇÃO ANTROPOGÊNICA NAS UNIDADES GEOECOLÓGICAS}

Devido às características morfológicas, a unidade que concentra o maior índice de 


\section{ANÁLISE GEOECOLÓGICA DA PAISAGEM COSTEIRA DO MUNICÍPIO DE ARACAJU/SERGIPE}

ocupação dentre todas é o Terraço Marinho. Cerca de $68,8 \%$ do total da área ocupada está sobre essa unidade. Tal ocupação é caracterizada por padrões de assentamento distintos - padrão disperso/horizontal e organizado em loteamentos na Zona de Expansão e concentrado/vertical nos bairros Coroa do Meio e Atalaia (Figura 9). Decorrente da maior concentração nos bairros Atalaia e Coroa do Meio, as características da unidade natural foram em grande parte suprimidas.

Para o caso da Zona de Expansão, inferese que não obstante nesta localidade não tenha acontecido a supressão total das características naturais em razão da ocupação dispersa, tal padrão de assentamento também gerou impactos consideráveis à unidade. É notório que a perda de área foi relativamente pequena, uma vez que ainda há muitos espaços vazios entremeando as áreas efetivamente ocupadas. No entanto, essa forma de ocupação tornou-se incompatível com a estruturação da unidade, pois algumas feições, a exemplo dos cordões litorâneos, tiveram sua continuidade interrompida pela ocupação. As características apontadas fizeram surgir na paisagem um padrão reticulado que, como explicitado, acaba por gerar impactos a partir do momento que se contrapõe a estruturação natural da unidade.

A ação antrópica ainda é manifesta em unidades como o Campo de Dunas, que nos últimos anos tem passado por constantes aterramentos e desmontes (Figura 9-a). Atualmente, cerca de $26,5 \%$ da unidade encontra-se ocupada, principalmente por padrões de loteamentos destinados à segunda residência e moradia fixa.

A evolução natural das dunas frontais foi interrompida pela construção de uma rodovia que basicamente a separa das dunas fixas e semifixas, restringindo parcialmente a troca de sedimentos entre as subunidades. Além da rodovia, a maior parte dos bares/restaurantes estão localizados sobre as dunas frontais, fato que resultou na supressão de muitas dessas. 
MOTA, L.S.M. e SOUZA, R.M.

\section{ANÁLISE GEOECOLÓGICA DA PAISAGEM COSTEIRA DO MUNICÍPIO DE ARACAJU/SERGIPE}

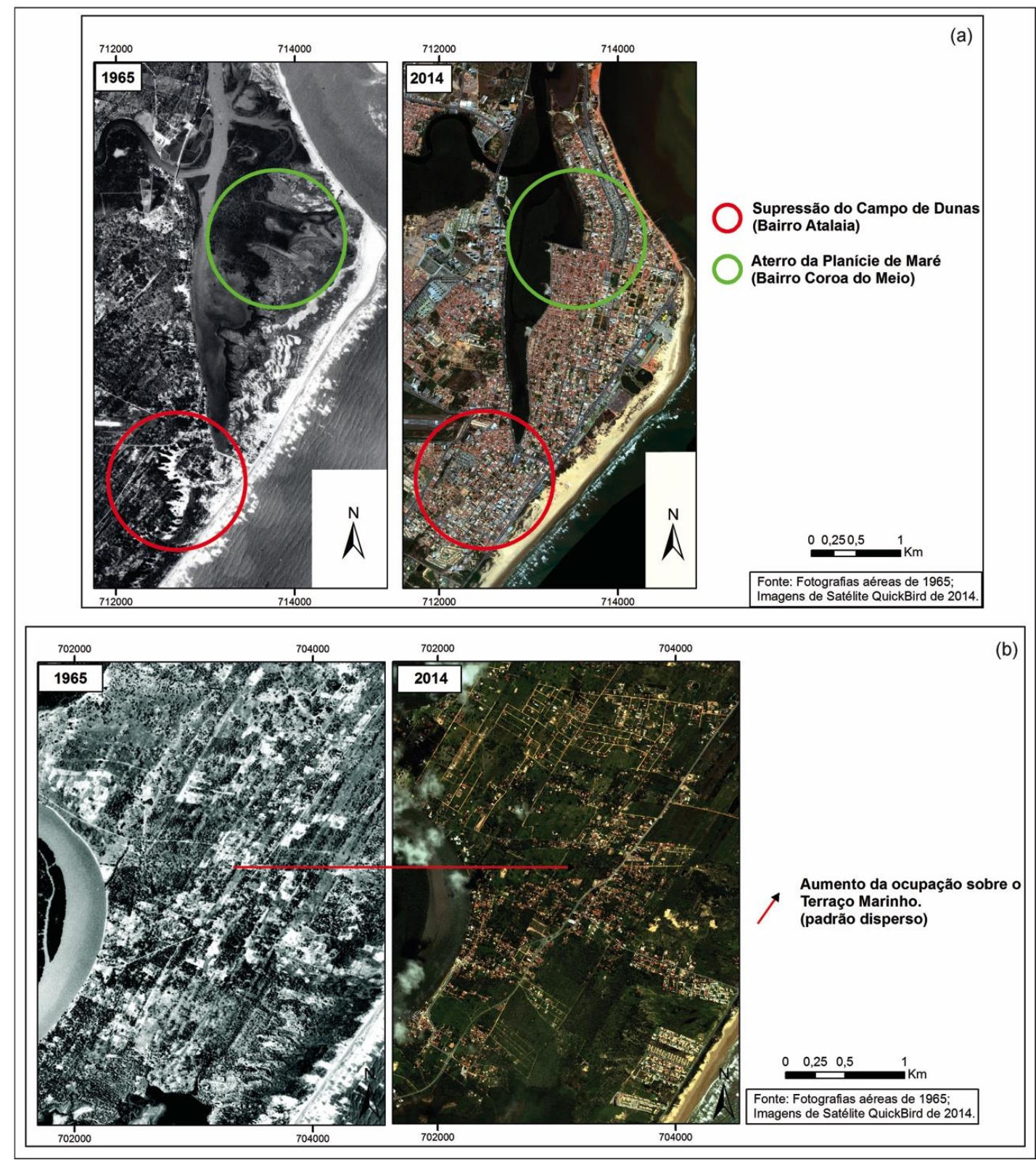

Figura 09 - Intervenção antrópica sobre as unidades geoecológicas nas últimas cinco décadas. Em (a): Supressão do Campo de Dunas e da Planície de Maré. Em (b): Aumento de área ocupada sobre o Terraço Marinho.

Quanto à unidade da Planície de Maré, enfatiza-se a subunidade dos manguezais. Esta foi fortemente impactada durante o período de constituição do bairro Coroa Meio em razão da supressão e aterramento dos manguezais ali presentes (Figura 9-a). Apesar disso, ainda é possível visualizar grandes extensões de manguezais associados à desembocadura do rio Vaza-Barris, em razão dos menores índices de ocupação.
Diferentemente das outras unidades estudadas, a unidade de Ambientes de Sedimentação Recente é a que possui os menores índices de derivação antropogênica, haja vista não apresentar nenhum tipo de ocupação fixa, embora algumas áreas sofram com a intervenção humana de forma indireta.

No relativo às praias, destaca-se a presença de bares e restaurantes, localizados externamente ao pós-praia (dunas frontais), que 


\section{ANÁLISE GEOECOLÓGICA DA PAISAGEM COSTEIRA DO MUNICÍPIO DE ARACAJU/SERGIPE}

acabam por interferir no ambiente praial. Ressalva-se apenas a praia dos Artistas e a Atalaia, cujas dinâmicas foram alteradas em razão da construção de estruturas de contenção na desembocadura do rio Sergipe, gerando derivações desta paisagem não mais somente ligadas à ação natural.

Todas as intervenções descritas estão associadas aos processos geoecológicos degradantes, os quais resultam na perda de atributos e propriedades sistêmicas que garantem o cumprimento das funções geoecológicas e os mecanismos de autoregulação (RODRIGUEZ; SILVA; CAVALCANTI, 2004). Tal circunstância pode ser associada às derivações antropogênicas da paisagem (MONTEIRO, 2001) tendo em vista que quanto mais alterada for uma paisagem, maior será a perda das suas funções geoecológicas naturais, mais degradado será o sistema e maior será a dificuldade deste recobrar-se frente a eventos de ordem natural ou antrópica.

\section{CONSIDERAÇÕES FINAIS}

O estudo da paisagem costeira de Aracaju foi alicerçado nos preceitos trazidos pela Geoecologia, cujos princípios metodológicos estão relacionados à análise síncrona entre dinâmica natural e dinâmica da produção social, as quais determinam a evolução geral das paisagens.

Embasado na individualização tipológica da paisagem foram delimitadas seis unidades geoecológicas e suas subunidades, analisadas sobre três dos enfoques analíticos da paisagem estrutural, funcional e antropogênico. Em face do que foi apresentando no decurso do trabalho, constatou-se que a gênese das unidades estão relacionadas primordialmente à dinâmica natural, com destaque para os agentes fluviomarinhos, a exceção dos depósitos tecnogênicos cuja origem está essencialmente interligada a ação antrópica. As estrutura e função desempenhada por estas unidades estão diretamente relacionadas à dinâmica da paisagem costeira, cuja principal característica é a elevada dinamicidade.
A contínua interferência antrópica provocou alterações na estrutura da paisagem analisada, em que se destacam: Terraço Marinho - supressão dos cordões litorâneos e aterro progressivo dos baixios úmidos e lagoas; Planície de Maré - aterro do manguezal associado à margem direita da desembocadura do rio Sergipe, cuja derivação originou os depósitos tecnogênicos; Campo de Dunas - supressão completa das dunas fixas localizadas no bairro Atalaia, desmonte progressivo das dunas fixas associadas à Zona de Expansão, interrupção do campo dunar pela rodovia dos Náufragos, desmonte de dunas frontais para construção de bares e restaurantes; Ambientes de Sedimentação Recente - construção de estruturas de contenção que alterou a dinâmica sedimentar das praias contidas nos bairros Coroa do Meio e Atalaia.

Assim, a despeito de componente desse sistema, o ser humano tem figurado como um agente desregulador, pois grande parte das intervenções tem rompido com a estruturação natural das unidades. Uma das principais inferências desse estudo é que em um possível cenário de concretude da ocupação total paisagem costeira aracajuana, prospecta-se a emergência de grandes impactos ao ambiente natural. À vista disso, urge a necessidade de mudanças na condução da cidade, ou esta continuará a ser inviabilizada, não só do ponto de vista dos problemas urbanísticos, mas, principalmente, do ponto de vista ambiental.

\section{REFERÊNCIAS BIBLIOGRÁFICAS}

BERTRAND, G. Paisagem e Geografia Física Global. Esboço Metodológico. Caderno de Ciências da Terra. Instituto de Geografia da Universidade Federal de São Paulo, n. 13, 1972. Traduzido por: Olga Cruz, publicado em: R.RA'E GA, Curitiba, n.8, p. 141- 152, 2004.

BITTENCOURT, A.C.S.P.; MARTIN, L.; DOMINGUEZ, J.M.L.; FERREIRA, Y.A. Evolução Paleogeográfica Quaternária da Costa do Estado de Sergipe e da Costa Sul do estado de Alagoas. Revista Brasileira de Geociências. São Paulo, 13(2), p. 93-97, 1983. 


\section{ANÁLISE GEOECOLÓGICA DA PAISAGEM COSTEIRA DO MUNICÍPIO DE ARACAJU/SERGIPE}

BÓLOS, M.C. Problemática Actual de los Estudios de Paisaje Integrado. Revista de Geografia. Barcelona, v.15, p. 45-68, 1981.

CARVALHO, M.E.S.; FONTES, A.L. Caracterização Geomorfológica da Zona Costeira do Estado de Sergipe. In: VI SIMPÓSIO NACIONAL DE GEOMORFOLOGIA. Goiânia, 2006.

CUNHA, F.M.B. Aspectos Morfológicos da Costa de Sergipe ao Sul de Aracaju. Boletim Técnico da Petrobrás. Rio de Janeiro, v.23, p.73-80, 1980.

DIAS, R.L.; OLIVEIRA, R.C.de. Análise das paisagens do litoral sul do estado de São Paulo. Sociedade e Natureza. Uberlândia, n.3, p. 505518, 2012.

DOMINGUEZ, J.M.L., BITTENCOURT,A.C.S.P., E MARTIN, L. O papel da Deriva Litorânea de Sedimentos Arenosos na Construção das Planícies Costeiras Associadas às Desembocaduras dos rios são Francisco (SE/AL), Jequitinhonha (BA), Doce (ES) e Paraíba do Sul (RJ). Revista Brasileira de Geociências. v.13(2), p. 98-105, 1983.

FONTES, A.L. O Quaternário Costeiro e o Município de Aracaju (SE). In: II CONGRESSO SOBRE PLANEJAMENTO E GESTÃO DAS ZONAS COSTEIRAS DOS PAÍSES DE EXPRESSÃO PORTUGUESA. IX CONGRESSO DA ASSOCIAÇÃO BRASILEIRA DOS ESTUDOS DO QUATERNÁRIO. ॥ CONGRESSO DO QUATERNÁRIO DOS PAÍSES DE LÍNGUA IBÉRICA, 2003.

EMBRAPA. Sistema Brasileiro de Classificação de Solos. 2a Ed. Rio de Janeiro, 2006.

FITZGERALD, D.M. Interactions between the EbbTidal Delta and Landward Shoreline: Price Inlet, South Carolina. Jornal of Sedimentary Petrology. v. 54, n. 4, 1984.

FRANÇA, S.L.A.; REZENDE, V.F. A Zona de Expansão Urbana de Aracaju: Dispersão Urbana e Condomínios Fechados. In: SIMPÓSIO NACIONAL DE GEOGRAFIA URBANA. Belo Horizonte - MG, 2010.

MACHADO, E.V. Aracaju: "Paisagens e Fetiches". Abordagens acerca do processo de seu crescimento urbano recente. 1989. Tese de Doutorado, UFSC, Santa Catarina.

MONTEIRO, C.A.F.de. Derivações antropogênicas dos geossistemas terrestres no Brasil e alterações climáticas: perspectivas urbanas e agrárias ao problema da elaboração de modelos de avaliação. RA'E'GA - O Espaço Geográfico em Análise. v. 5, 2001.

MOTA, L.S.O. Avaliação Geoecológica e dos Riscos Ambientais na Paisagem Costeira de Aracaju/SE. 2017. Doutorado em Geografia Programa de Pós-Graduação em Geografia, Universidade Federal de Sergipe, São Cristóvão. MOTA, L.S.O. Morfodinâmica Estuarina e Variações do Delta de Maré- Vazante no Rio Vaza-Barris, SE, Brasil. Revista Brasileira de Geomorfologia. São Paulo, v.16, n.4, p.641-656, 2015.

RODRIGUEZ, J.M.M.; SILVA. E.V.da; CAVALCANTI, A.P.B. Geoecologia das Paisagens: Uma visão geossistêmica da análise ambiental. 1ạ Edição. Fortaleza: Editora UFC, 2004.

TRICART, J. A Geomorfologia nos Estudos Integrados de Ordenação do Meio Natural. Boletim Geográfico. Traduzido por: Lucy Pinto Galego. Rio de Janeiro, 34(251), p. 15-42, 1976.

TROLL, C. A paisagem geográfica e sua investigação. Publicado originalmente em "Die geographísche landschaft und ihre Erfosschung Studium Generale, 4-5, 1950. Traduzido por: Gabrielle Corrêa Braga. Espaço e Cultura. Rio de Janeiro, n.4, 1997.

TROLL, C. Landscape Ecology (Geoecology) and Biogeooenoiogy - A Terminological Sdudy. This article was published in German in Revue de Geoiogie, Gkoplrysiqueef Gkgmpizie. Serie de Geographic, vol. 14, n. 1, p.9-18, 1970.

VILAR, J.W.C. A Zona de Expansão de Aracaju: Contribuição ao Estudo da Urbanização Litorânea de Sergipe. In: VILAR, J.W.C.; ARAÚJO, H.M. de. Território, Meio Ambiente e Turismo no Litoral Sergipano. São Cristóvão: Ed. UFS, 2010 